„Bohemistyka” 2020, nr 3, ISSN 1642-9893

Michaela KŘIVANCOVÁ

DOI: $10.14746 /$ bo.2020.3.8

České Budějovice

\section{The notional and pragmatic components of literal, figurative, and/or transferred meaning of phrasemes}

Keywords: Czech phraseology, phraseological unit, notional meaning, pragmatic meaning, literal meaning, figurative meaning, transferred meaning

\section{Abstract}

This paper examines the notional and pragmatic components of the meaning of the Czech phrasemes containing names of fairy-tale creatures. We do not aim for exhaustive evidence of phrasemes from thematic unit Names of fairy-tale creatures, but we are trying to prove on a few concrete examples that phrasemes 1) can solely convey literal meanings (either notional or pragmatic, or both notional and pragmatic), or, 2) in addition to verbatim meaning, they can also acquire figurative and/or transferred meaning (namely notional, or pragmatic, or both national and pragmatic concurently). In this paper, we prove that the traditionally postulated concept of Czech phraseology does not apply, namely that each phrasemes is represented by both (a notional and a pragmatic) component of meaning. On the contrary, it appears that some phraseological units can only be of notional significance, other phrasemes can only have pragmatic significance.

\section{Introduction}

In this paper the focus of our inquiry were the notional and pragmatic components of the meaning of the Czech phrasemes (the phraseological units; the phraseological expressions; the phraseologism), with special emphasis on phraseological units containing names of fairy-tale creatures. Apart from phrasemes containing the name of a fairy-tale creature, our research also encompasses expressions which denominate a fairy being as a whole without mentioning the creature itself. All phraseological expressions mentioned in this paper and highlighted by bold font were excerpted from the lists and diction- aries of Czech phraseology included in our bibliography. Far from providing detailed information on the excerpts from the given thematic whole ${ }^{1}$, our aim is to document through a few concrete phrasemes all theoretical findings revealed by our research into the types of meaning expressed by phraseological units.

\section{Phraseological units}

Our perception of the phraseme as a combination of words of semiotic nature which integrates the expressional component (serving in the text as a phraseme) and the meaning as a semantical-functional (idiomatic) component, is in correspondence with the conception formulated e. g. by E. Mrhačová (2003) or by F. Čermák (2007). Both of these components are by nature inseparable: there is no phraseological form (expression) not conveying a meaning, and, on the other hand, it impossible for a meaning (idiom) not to receive a formal structure. For the purposes of analysis, Čermák distinguishes between the phraseme and the idiom - in Nový encyklopedický slovník češtiny (2017, online) he says:

[...] analyzuje-li se kombinatorický útvar formálně, z hlediska formálních rysů, mluví se o frazému, zatímco analýza sémantická, z hlediska relevantních sémantických rysů, opravňuje užití názvu idiom.

$[\ldots$ if it is the form of a combinatorial unit that is analysed, with regard to its formal features, reference is made to the phraseme, whereas a semantical analysis, with regard to relevant semantic features, justifies the term idiom].

But, if we talk in this paper about phraseme, phraseological unit, phraseologism, phraseological collocation, phraseological compound etc., we heave in mind the phraseme in a wider sense, i.e. phraseme as a mark - it means close connection of the two above mentioned components, formal and semantic. If in a particular section of our exposi-

${ }^{1}$ The complete list and classification of excerpts from the defined thematic set "The Names of fairy creatures in Czech phraseology" was presented elsewhere (Křivancová 2015, 2016, 2017). 
tion, it is necessary to accentuate the expressional structure of a phraseological unit, we use the collocation "formal expression" ("linguistic/phraseological form" or "expressional component"/“expression"). If it is necessary to emphasise the meaningful segment of a unit, reference is made to the "meaning" or to the "semantic aspect" of the phraseme.

On that account, our ambition is not to summarise various insights into the phrasemes, which are mentioned in phraseological publications (cp. e. g. Zaorálek 1947, Šmilauer 1972, Mlacek 1977, Bečka 1982, Hladká 1995, Čermák 2009a-d, Flajšhans 2013), nor do we attempt to propose comprehensive definitions of our own. The phraseological unit is viewed in this paper as it has appeared from our excerpts: in some features we agree with its definition by Hladká in Př́ruční mluvnice češtiny (1997) or by Čermák in Nový encyklopedickýslovník češtiny (2017, online), so we understand it as a fixed combination of a minimum of two words conveying a meaning as a whole (for the most part underivable from the meaning of its constituents), with at least one of its components in a particular function being solely reduced to this combination or a few others. Concomitant attributes, as mentioned by Hladká or Čermák, may be metaphoricality, expresivity, or occurence of archaisms.

In addition, we also perceive secondaryity of the naming as another necessary feature of phrasemes, with primary naming being understood as naming of a previously unnamed reality. In other words, if there is a phraseological form, then it is always possible to create a meaning parallel using "regular" language, i.e. to express it by means of a primary (and thus non-phraseological) naming. Therefore, if, for example, we use the structure "baba jaga" to denote the creature itself, it is its primary naming (the naming of the so far unnamed "reality"). This structure thus cannot have a phraseological character, since it is not a secondary naming for that fairy-tale. However, if we denote a real (not a fairy-tale) $)^{2}$ being with this phrase, then it is already

${ }^{2}$ Real creatures are from the real world, whereas fictional (i.e. fairy) creatures are beings from a fictional world. The dichotomy of real creatures versus fictional the secondary (and therefore phraseological) naming. In such a case, we denominate secondarily such a being that would be primarily denoted as, for example, an evil, old, contentious, and, usually, ugly woman.

\section{Types of phrasemes meanings}

In most cases, phraseological collocations have two meanings: a literal (compositional, direct) meaning and a figurative, or transferred meaning (a figurative and a transferred meaning may be concomitant). The literal meaning results from the meanings of individual components as their "aggregate" and, habitually it is not important, for it has mostly no informative value. For example, the literal meaning of the phraseme jit se podivat na strašidlo [to go and look at the ghost] corresponds to the literal form, i.e. "jít se podívat na strašidlo". The figurative and/or transferred meaning is usually derived implicitly from the established combination of input components. Thus the phraseological form jit se podivat na strašidlo matches the figurative meaning "jít čůrat" [to go and have a pee]; the phraseological form $T a$ $v i$, kde čert večeři [she knows where the devil dines] corresponds with the figurative meaning "je klevetnice" [she is a gossiper]; etc.

All along with it, every phraseological unit does not necessarily bear a figurative or transferred meaning. So the set phrase can function as a secondary denomination (fulfilling its phraseological purpose) although it has / may have only the literal meaning. Such phrasemes, including those serving the denominative function, have a minimum incidence. It should be noted that it is not only the appellative act (assigning a linguistic form to a particular content) that is currently connected with designation (denomination), but the result of the denominative process (the nominative unit) is attributed to it likewise, hence both words and established collocations (as well as phraseologisms)

creatures (as real world versus fictional world) is used in correspondence with the terms of Lubomír Doležel, used in publication Heterocosmica. Fikce a možné světy (Praha: Karolinum, 2003). 
are termed denominations today (cp. Hladká 2017b, online). Similarly, F. Čermák in the Nový encyklopedický slovník češtiny in the frazeologie a idiomatika entry specifies:

Tím, že frazém je v textu víceslovným a ustáleným jaz. pojmenováním, založeným sémioticky a psychologicky, plní svou primární nominativní funkci [...]

[The phraseme serves its primary denominative purpose through functioning as a multi-word and fixed appellation grounded in semiotics and psychology...] (Čermák 2017, online).

Just as J. Filipec and F. Čermák’s in Česká lexikologie (1985) relate the meaning of collocational idiomatic denominations to entities (persons; things, etc.), qualities, processes, states and conditions; and the meaning conveyed by propositional idiomatic appellations then accords with events. The same authors supplement their range of idiomatic denominations by expressions that „mezi idiomatická pojmenování však patří i výrazy pojmenovávající relace, funkce, operace, deixi, modalitu aj.“ "[,denote relations; functions; operations; deixis; modality; etc."] (Filipec, Čermák 1985, p. 188). Since the centre of our attention are phrasemes with an appellative function (phraseological denominations in short), our use of the term implies the narrower concept, namely that expressing only the meaning that corresponds to entities (i.e. substances). As for the expressional structure, it involves a multi-word appellation of a fairy creature alone with the denomination concurrently being a secondary, not primary, appellation. It is only this mode that can effect the term's phraseological relevance and justify it as the frazeologické sousloví [phraseological compounds].

As we have already mentioned, every phraseological unit does not necessarily bear a figurative or transferred meaning. This type of denominations with denominative function can be exemplified by phrasemes that as a whole refer to fictional beings (e.g. zelený mužik / vodní mužíček [green manikin / water sprite ] = 'vodník' [water elf]) or biblical beings (e.g. královna nebes [Queen of Heaven] = 'Panna Marie' [Virgin Mary]). The literalness of the meaning of the expression corresponds here with the direct motivationality affecting the re- lation between the components and the phraseological whole. If the global significance of a phraseological unit is directly motivated by individual components and therefore it is derivable from the meanings of single segments, the phraseological expression then has a literal meaning. At the same time, both the expressional and semantic characteristics of the phraseme (namely the phraseme in a narrower sense and the idiom) must relate to the identical entity from the identical sector of a potential world ${ }^{3}$ (e.g. both marks of the phraseme as a sign refer to plants; to real beings; to fictional creatures; etc.) and reciprocally function as full synonyms. Zelený mužik, vodni mužičck and vodnik denote the same fictional (fairy) being: 'vodník' is defined as a water-dwelling green male (= zelený mužík; vodní mužíček); královna nebes and Panna Marie also denote the same beings: 'Panna Marie' is defined as Queen of Heaven (= královna nebes). In contrast, královna sportu [a queen of sport] does not refer to a queen who is good at sport, but the expression refers to sports - athletics, i.e. a completely different entity; královna květin [a queen of flowers] does not refer to a queen who would rule over flowers, but it refers to a particular flower - the rose, etc. This is a transferred appellation, not a literal denomination.

Also we have already mentioned, that in the case of appellative collocations of fairy beings it is necessary to consider whether it is a primary or secondary denomination: only the secondary denomination collocation can be understood as a phraseological collocation. If, for example, the expression mořská panna is used to denominate a fairy being, it is a primary appellation, not a phraseme. However, if the collocation mořská panna, denominates anyone except a fairy creature, it is definitely a secondary (i.e. phraseological) appellation of a (sea) water-loving person.

${ }^{3}$ Out perception of the terms entity and potential world is identical with Lubomír Doležel, used in the publication Heterocosmica. Fikce a možné světy (Praha: Karolinum, 2003). 


\section{Comparation of traditional and our concepts}

The semantic significance of the phraseological unit (idiom) on the one hand comprises a notional (conceptual; ideational; factual; cognitive) meaning, and, on the other hand, it has a pragmatic (connotative) meaning which embraces mainly expressive and evaluative components. Čermák (2007, p. 7) evaluates it as follows:

Na rozdíl od významu nocionálního nelze pragmatickým typům významu obvykle přriřadit zřetelný sémantický rys jednoznačně, popř. Vůbec.

[Unlike the notional meaning, pragmatic types of meaning usually cannot be unambiguously assigned a perspicuous semantic feature, or none at all.].

Nevertheless, these pragmatic components, if they are part of the semantic structure of a particular phraseme, supplement the notional meaning with other marks. The pragmatic components of the meaning thus share in structuring the definite significance of the whole expression.

The notional meaning of the phraseme corresponds to the factual content of the literal meaning (if a phraseme is lacking in metaphorical or figurative meaning), or it corresponds to the factual content of the metaphorical and/or figurative meaning of the phraseme (if the given phraseme carries a metaphorical and/or figurative meaning). Thus vodní mužíček, for example, conveys a literal, not metaphorical or figurative, meaning, i.e. it refers to a water-dwelling creature; from the pragmatic features of the meaning, it is possible to separate an emotionally positive aspect of the meaning (revealed through the positive connotations of the diminutive "mužíček". The collocation Šlo ke všem čerti̊m delivers a figurative meaning which is approximately defined in phraseological dictionaries as "zničilo se to" [it was ruined]. The notional meaning "zničilo se to" is accompanied by a pragmatic element of the meaning testifying to negative connotations.

In reference to the two segments of meaning, i.e. notional and pragmatic, J. Filipec and F. Čermák say:
Poměr zastoupení obou složek se u různých výrazů značně liší. Základní je funkce dezignativní, založená na vztahu frazému jako znaku $\mathrm{k}$ jeho denotátu a nocionáln (konceptuální) složce jeho významu; je společná pojmenováním všech druhů. Pragmatická funkce, založená na (subjektivním) vztahu účastníků promluvy $\mathrm{k}$ frazému, je naproti tomu zvláště výrazná v IF. Zprostředkovává obecně různé subjektivní aspekty mluvčími při komunikaci zdůrazňované (zvláště emocionální a postojové) [...]. [...]; každý frazém má však v sobě zastoupeny v různé míře složky obě (Filipec, Čermák 1985, p. 232).

[The incidence ratio of both components in various expressions considerably varies. The basic function is designative, based on the relationship between the phraseme as a sign to its denoted item and to the notional (conceptual) aspect of its meaning; its shared through denominating all varieties. The pragmatic function, based on the (subjective) relationship of the discourse participants to the phraseme, is by contrast particularly distinctive in idiomatics and phraseology. It mediates generally divers subjective aspects emphasised by the speaker during the communication (specifically emotions and attitudes) [...]. [...]; every phraseme, however, contains to a varying extent both components]

At any rate, our thematically oriented corpus reveals that some phraseological units carry only the notional meaning, without the pragmatic addition. This is documented e.g. by the collocation král nebeský (a secondary denomination of God or Christ), or by královna nebes (a secondary denomination of Panna Marie). In these units, the expressions "king" or "queen" refer to a male or female ruler, and the meanings of these words are not denied even in global meanings of these phraseological units. The meanings of these structures are only expanded by the attribute "heavenly / heaven", which specifies the environment in which these beings rule. Here, it is not about fairy-tale characters, but about religious figures. In Christian beliefs, God is defined as the "king ruling in Heaven" ("the king of Heaven") and the Virgin Mary as the "queen ruling in Heaven" ("the queen of Heaven"). These phraseological units do not carry pragmatic components of meaning, i.e. neither the form of individual components nor the phrase as a whole exhibits any features of emotional or evaluative attitude of the speaker, nor do they carry any social features (e.g. explicity expressed courtesy or discourtesy) or other marked features, and as a whole they do not fulfil the communicative function, but the „neu- 
tral" naming function (they "matter-of-factly" denote religious characters as those who rule in heaven).

Other types of phrasemes bear both types of meaning, yet preferential is the pragmatic aspect of the meaning, as evident e.g. in the phraseme used in cheers: At' žije král! [Long live the king]. Some other phraseological units are completely lacking in the propositional content and so it is impossible to delimit in them any notional segment of meaning. Their significance is then constituted solely through pragmatic components. For example the phrasemes $K$ čertu!; $U$ všech čertů! etc. reflect the speaker's attitude to the discourse situation, expressing various communicational functions (the given examples are curses) [the deuce!, the dickens!].

\section{Conclusion}

Summing up, we can specify the types of meaning carried by units as described above, corroborating them by concrete examples of our excerpts (containing names of fairy-tale creatures). In this paper, we prove that the traditionally postulated concept of Czech phraseology does not apply, namely that each phrasemes is represented by both (a notional and a pragmatic) component of meaning. On the contrary, it appears that some phraseological units can only be of notional significance, other phrasemes can only have pragmatic significance.

The phraseological significance can be described as:

1) literal, specifically:

a) o n 1 y n o ti o n a l: e. g. král nebeský; královna nebes

b) only prag matic: e. g. At'žije král! (cheers)

c) notional and pragmatic: e. g. vodni mužiček; zelený mužik

2) transferred and/ or figurative, namely:

a) on ly noti on a l: e. g. mořská panna (never denominating the fairy being proper)

b) o n ly pragmatic: e. g. K čertu! (curse)

c) notional a n d prag mat i c: e. g. Šlo to ke všem čertům.
The paper did not aim to summarize the complete corpus of phrasemes with names of Fairy-tale creatures. The purpose of this artikle is to document through several concrete phrasemes all theoretical findings made about type sof meaning of phraseological units.

\section{Sources}

B e č k a J. V., 1982, Slovník synonym a frazeologismů. 3rd edition. Praha: Novinář

Č e lakovský F. L., 1949, Mudrosloví národu slovanského ve príslovích. 3rd edition. Praha: Vyšehrad.

Č e r má k F. a kol., 2009a, Slovnik české frazeologie a idiomatiky. 1st vol. Praha: LEDA.

Č e r m á k F. a kol., 2009b, Slovník české frazeologie a idiomatiky. 2nd vol. Praha: LEDA.

Č e r má k F. a kol., 2009c, Slovník české frazeologie a idiomatiky. 3rd vol. Praha: LEDA.

Č e r m á k F. a kol., 2009d, Slovník české frazeologie a idiomatiky. 4th vol. Praha: LEDA.

Č e rmák F., Holub J., 2016, Slovník české frazeologie a idiomatiky. 5th vol. Onomaziologický slovnik. Praha: LEDA.

D o brovský J., 1963, Českých přisloví sbirka. Prepared by Heřman, M. Praha: Nakladatelství Československé akademie věd.

F 1 a j š h a n s V., 2013, Česká př́sloví. Sbirka prísloví, průpovédí a pořekadel lidu českého v Čechách, na Moravě a v Slezsku. (2 volumes). 2nd edition. Olomouc: Univerzita Palackého.

Slovník spisovné češtiny pro školu a veřejnost, 2004, reprint 3rd edition. Praha: Academia.

Z a o rá le k J ., 2000, Lidová rčení. 4th edition. Praha: Academia.

\section{References}

Č e r m á k F., 2007, Frazeologie a idiomatika česká a obecná. Praha: Karolinum.

Č e r m á k F., 2017, Frazém a idiom. In: P. Karlík - M. Nekula - J. Pleskalová (eds.), CzechEncy - Nový encyklopedický slovník češtiny. Brno: FF MU. Online: https://www.czechency.org/slovnik/FRAZÉM IDIOM (cit. 1.09.2018).

Č e r m á k F., 2017, Frazeologie a idiomatika. In: P. Karlík, M. Nekula, J. Pleskalová (eds.), CzechEncy - Nový encyklopedický slovník češtiny. Brno: FF MU. Online: https://www.czechency.org/slovnik/FRAZEOLOGIE A IDIOMATIKA (cit. 3.09.2018).

D o 1 e ž e 1 L., 2003, Heterocosmica. Fikce a možné světy. Praha: Karolinum. 
F i li pe c J., Č e r mák F., 1985, Česká lexikologie. Praha: Academia.

H l a d ká Z., 1995, Frazémy. In: Přiruční mluvnice češtiny. Eds. P. Karlík, M. Nekula, Z. Rusínová, Praha: Nakladatelství Lidové noviny.

H l a dká Z., 2017, Pojmenování. In: P. Karlík, M. Nekula, J. Pleskalová (eds.), CzechEncy - Nový encyklopedický slovník češtiny. Brno: FF MU. Online: https://www.czechency.org/slovnik/POJMENOVÁNÍ (cit. 30.08.2018).

Kř iv a n c ová M., 2017, Pojd'te s námi do pohádky. Obraz pohádkových bytostí $v$ české frazeologii. „Acta FF ZČU. Moderní lingvistika mezi pragmatickým a kognitivistickým prístupem" 9, č. 2, s. 67-100.

Kři v a n c ová M., 2016, Čertovský guláš - druhá část. (Obraz čerta v české frazeologii). „Lingua Viva“ XII, č. 22, s. 34-45.

Kři va n c ová M., 2015, Čertovský guláš - prvni část. (Obraz čerta v české frazeologii). „Lingua Viva“ XI, č. 21, s. 41-48.

M 1 a c e k J., 1977, Slovenská frazeológia. Bratislava: Slovenské pedagogické nakladatelstvo.

Mrhač ová E., 2003, Prémie se zooapelativem jako bázovým slovem v češtinè a polštině. In: Prémie národi̊ slovanských. Sborník přispěvků z mezinárodní konference konané v Ostravě ve dnech 20.-21.11.2002 u př́ležitosti 150. výroči úmrtí F. L. Čelakovského a vydání jeho »Mudroslovi«. Ostrava: Filozofická fakulta Ostravské univerzity, s. 107-115.

Š m i l a u e r V., 1972, Nauka o českém jazyku. Praha: SPN. 